\title{
The Effectiveness of Learning Tools Using the 5E Learning Cycle Model to Improve Mastery of Concepts and Generic Science Skills
}

\author{
Ihda Shoumi Nurdini ${ }^{1}$, Suyatno Sutoyo ${ }^{1}$, Pirim Setiarso ${ }^{1}$ \\ ${ }^{1}$ Science Education, Postgraduate University of Surabaya, Surabaya 60231, Indonesia
}

DOI: $\underline{10.29303 / \text { jppipa.v7i2.672 }}$

\section{Article Info}

Received: February 26th, 2021

Revised: March 30th, 2021

Accepted: April 6th 2021

\begin{abstract}
This study aims to determine the effectiveness of learning devices using the $5 \mathrm{E}$ learning cycle model to improve students' mastery of concepts and generic science skills in electrolyte and non-electrolyte solutions. This research is a type of pre-experimental research with one group pretest-posttest design research design. The research subjects were 21 students of class X MIPA-1 MA YKUI Maskumambang, Gresik, East Java. The methods used in data collection include validation and tests. The research data were analyzed descriptively and the n-gain analysis was used to determine the increase in students' mastery of concepts and generic science skills. The results showed: (1) students' mastery of concepts in electrolyte and non-electrolyte solutions was 0.8 with high criteria; (2) The average score of the students' mastery of concepts on electrolyte and non-electrolyte solutions was 89; (3) Increasing students' generic science skills on electrolyte and nonelectrolyte solution material by 0.8 with high criteria; and (4) The average value of generic science skills for observation skills is 96 with predicate A. Based on the results of this study, it can be concluded that the learning device using the $5 \mathrm{E}$ learning cycle model is effective in improving students' mastery of concepts and skills in electrolyte and non-electrolyte solution material.
\end{abstract}

Keywords: Learning cycle 5E; mastery of concepts; generic science skills; electrolyte and non-electrolyte solutions.

Citation: Nurdini, I., Sutoyo, S., \& Setiarso, P. (2021). The Effectiveness of Learning Tools Using the 5E Learning Cycle Model to Improve Mastery of Concepts and Generic Science Skills. Jurnal Penelitian Pendidikan IPA, 7(2), 184-190. doi:https://doi.org/10.29303/ippipa.v7i2.672

\section{Introduction}

The revised 2013 curriculum is the current curriculum in Indonesia. Chemistry is one of the subjects that contains basic competencies which reads "analyzing the properties of solutions based on their electrical conductivity" for knowledge competencies and "distinguishing the electrical conductivity of various solutions through the design and implementation of experiments" for skills competencies (Ministry of Education and Culture, 2016). The two basic competencies are related to electrolyte and non-electrolyte solution material which is material that contains concepts that are not sufficient to memorize but there are concepts that need to be observed by carrying out practicum activities, one of which is through the generic science skills approach.

This is based on the opinion of Sudarmin (2012) that generic science skills are basic scientific skills that are general in nature and can be developed in students through learning in the field of science. Then Ulia, et al (2017) explained that generic science skills are skills that combine cognitive abilities with psychomotor abilities that exist in students in a complex manner so that it is expected that students' abilities in the psychomotor field are accompanied by mental functions that are cognitive in nature.

Saprudin, et al (2010) explained that learning concepts and solving various problems in life, 
especially those related to science, requires generic science skills. Then Virtanen, et al (2018) added that this generic science skill is predicted to be emphasized in the world of work in the future (21st century). Based on the description above it can be concluded that generic science skills are a general basic skill that combines cognitive and psychomotor abilities so that the generic science skills in students can make it easier for students to find solutions to various life problems, especially those related to the field of science through activities experiment.

Ramdoniati, et al (2018) stated that chemistry is a science consisting of macroscopic, submicroscopic and symbolic materials, including electrolyte and non-electrolyte solution material. The matter of electrolyte and non-electrolyte solutions is also an abstract material so it is difficult to understand. This is in accordance with the results of pre-research as many as $61 \%$ of students stated that the material of electrolyte and non-electrolyte solutions which include the electrical conductivity of the solution, ionization reactions and grouping of covalent compounds and ionic compounds is difficult to understand material.

Based on the data on daily test scores at MA YKUI Maskumambang Dukun-Gresik for the 2019/2020 academic year, it is known that the average student score on electrolyte and non-electrolyte solution material is 58 . Then there are $61 \%$ of students who score below the KKM, which is 75 . This This is reinforced by the results of a questionnaire as many as $61 \%$ of students stated that the electrolyte material which includes the electrical conductivity of the solution, ionization reactions and grouping covalent and ionic compounds is a material that is difficult to understand. Then as many as $67 \%$ of students stated that they found it difficult to understand symbols in chemistry. Students also often find it difficult to explain the cause and effect of chemical phenomena. Direct or indirect observations of chemical phenomena are rarely carried out by students in learning. This shows that the generic science skills possessed by students still need to be trained again. However, students have often been trained to make conclusions from a phenomenon.

These problems can be overcome by applying a learning model. One of them is a learning model that is able to make students interactive and able to participate actively, one of which is by applying the 5E learning cycle model. Kusumawati \& Rivana (2017) in their research stated that the 5E learning cycle model was effective in improving students' understanding of generic science concepts and skills in invertebrate material. Then based on the results of research conducted by Putra et al (2018), it is stated that the use of the 5E learning cycle model can affect the increase in student motivation and understanding of student concepts applied to the concept of heat transfer.

Based on the background of the problem above, the researcher intends to conduct research with the title "The Effectiveness of Learning Tools Using the 5E Learning Cycle Model to Improve Mastery of Generic Concepts and Skills".

\section{Method}

This study aims to determine the effectiveness of the learning device using the $5 \mathrm{E}$ learning cycle model in terms of increasing students' mastery of concepts and generic science skills in electrolyte and non-electrolyte solution material. The subjects of this study were 21 students of class X MIPA 1 MA YKUI Maskumambang. This type of research is preexperimental research with a one group pretestposttest design research design which can be formulated as follows:

$$
\mathrm{O}_{1} \times \mathrm{O}_{2}
$$

Description:

O1 : The initial test was to measure the students' mastery of concepts in electrolyte and nonelectrolyte solution material as well as the generic science skills of students before getting treatment.

$X$ : The treatment given is in the form of learning using the $5 \mathrm{E}$ learning cycle model

O2 : The final test is to measure the students' mastery of concepts in electrolyte and nonelectrolyte solution material as well as the generic science skills of students after receiving treatment.

(Sugiyono, 2012)

Data on students' mastery of concepts and generic science skills were collected using a concept mastery test and a generic science skills test. Both data are expressed in numerical form from 1-100 then converted into A to D predicates as listed in Table 1.

Table 1. Convert Test Scores into Predicates

\begin{tabular}{lll}
\hline No & $\begin{array}{l}\text { Knowledge Competency } \\
\text { Value }\end{array}$ & Predicate \\
\hline 1 & $<75$ & D (less) \\
2 & $75-82$ & C (enough) \\
3 & $83-90$ & B (good) \\
4 & $91-100$ & A (Very Good) \\
\hline
\end{tabular}

(Kemendikbud, 2016) 
Students are said to be complete when they reach the KKM that has been determined by the education unit, namely obtaining a minimum of 75 equivalent to the $C$ predicate (Kemendikbud, 2016). The results of the concept mastery test during the pretest and posttest were analyzed using the N-gain score which is interpreted as an increase in students' mastery of concepts after the implementation of learning tools using the 5E Learning Cycle model, and calculated using the following equation:

$$
g=\frac{\text { Posttest value-pretest value }}{\text { Maximum value }- \text { Pretest value }}
$$

(Lestari and Mujib, 2018)

Furthermore, the criteria for increasing students' conceptual mastery of electrolyte and non-electrolyte solutions were determined using Table 2.
Table 2. Criteria for N-gain Score

\begin{tabular}{lll}
\hline No & N-gain Score & Kriteria \\
\hline 1 & $\mathrm{~g}<0.3$ & low \\
2 & $0.3 \leq \mathrm{g}<0.7$ & middle \\
3 & $\mathrm{~g} \geq 0.7$ & high \\
\hline & & (Lestari and Mujib, 2018)
\end{tabular}

\section{Results and Discussion}

\section{Learning Tool Validation}

This research activity begins with the development of learning tools to support learning with the $5 \mathrm{E}$ learning cycle model. The learning tools developed consist of a syllabus, lesson plans, student worksheet, student textbooks, concept mastery tests and generic science skills tests. Before being used in the research, all the tools were validated by three experts who are experts in chemistry education. The results of the validation of learning devices are presented in Table 3.

Table 3. Results of Learning Tool Validation

\begin{tabular}{llllll}
\hline No & Learning Media & Validation Score & Description & Reliability (\%) & Description \\
\hline 1 & Syllabus & 3.80 & Very Valid & 96.8 & Reliable \\
2 & Lesson plan & 3.80 & Very Valid & 93.3 & Reliable \\
3 & Student worksheet & 3.80 & Very Valid & 92.8 & Reliable \\
4 & Student textbooks & 3.80 & Very Valid & 90.9 & Reliable \\
5 & Concept Mastery Test & 3.50 & Valid & 85.7 & Reliable \\
6 & Generic Science Skills Test & 3.50 & Valid & 88.9 & Reliable \\
& Average & 3.70 & Very Valid & 91.4 & Reliable \\
\hline
\end{tabular}

Based on the data in Table 3, it can be stated that the average score of validation of learning tools developed is 3.70 with a very valid category, which means that the learning device developed is suitable for use as a learning tool. Meanwhile, the average reliability of learning devices is $91.40 \%$, so that all of these learning devices are classified as reliable (Pascalia et al, 2019).

Purwanto (2012) explains that learning tools which include syllabus, lesson plans, student worksheets, student textbooks, concept mastery tests, and generic science skills tests must meet the requirements as good learning tools, namely validity and reliability. Valid means that each measuring instrument only measures one aspect while being reliable means that each measuring instrument must be able to provide accurate, accurate, and unchanging measurement results. If the learning device meets the content and construct validity criteria, the learning device is said to be feasible as a learning tool (Tirmayasari, et al., 2019).
The effectiveness of the learning device using the $5 \mathrm{E}$ learning cycle model in this study was viewed from the students' mastery of concepts and generic science skills in the material of electrolyte and nonelectrolyte solutions.

\section{Mastery of Student Concepts on Electrolyte and Non-Electrolyte Solution Material}

The results of the research on the students' mastery of concepts on electrolyte and non-electrolyte solutions are listed in Table 4.

Table 4. Data on Concept Mastery Test Results

\begin{tabular}{llll}
\hline $\begin{array}{l}\text { Pretest } \\
\text { Average }\end{array}$ & $\begin{array}{l}\text { Posttest } \\
\text { Average }\end{array}$ & $\begin{array}{l}\text { N-gain } \\
\text { Average }\end{array}$ & $\begin{array}{l}\text { Classical } \\
\text { Completeness } \\
(\%)\end{array}$ \\
\hline 33 & 89 & 0.8 & 90 \\
\hline
\end{tabular}

Based on Table 4, it is known that the posttest score is higher than the pretest value with the average value of students' mastery of concepts in electrolyte and non-electrolyte solution material of 89 . The indicators of concept mastery in electrolyte and non- 
electrolyte solution material in this study are listed in Table 5.

Table 5. Indicators of Mastery of the Concept of Electrolyte and Non-Electrolyte Solutions

\begin{tabular}{ll}
\hline No & Concept Mastery Indicators \\
\hline 1 & $\begin{array}{l}\text { Grouping solutions based on their electrical } \\
\text { conductivity into electrolyte and non-electrolyte } \\
\text { solutions }\end{array}$ \\
2 & $\begin{array}{l}\text { Describe the properties of electrolyte and non- } \\
\text { electrolyte solutions based on their electrical } \\
\text { conductivity }\end{array}$ \\
3 & $\begin{array}{l}\text { Grouping solutions based on their electrical } \\
\text { conductivity into strong electrolyte solutions and } \\
\text { weak electrolytes. }\end{array}$ \\
4 & $\begin{array}{l}\text { Describe the properties of strong and weak } \\
\text { electrolyte solutions based on their electrical } \\
\text { conductivity. } \\
\text { Analyze that electrolyte solutions can be ionic } \\
\text { compounds and polar covalent compounds. } \\
\text { Analyze compounds including strong, weak or } \\
\text { non-electronite types of electrolytes based on the } \\
\text { type of chemical bond. }\end{array}$ \\
\hline
\end{tabular}

Students 'mastery of concepts on electrolyte and non-electrolyte solution material is measured using a concept mastery test based on the concept mastery indicators listed in Table 5.Based on this, it is known that the completeness of students' mastery of concepts on electrolyte and non-electrolyte solution material is classically known to be $90 \%$. The increase in students' mastery of concepts on electrolyte and non-electrolyte solution material that occurred was indicated by the average value of an increase in $\mathrm{N}$ Gain of 0.8 with high criteria. Ariska, Helen (2017) in their research stated that through the $5 \mathrm{E}$ learning cycle model, students are invited to learn something new or try to understand something that is already known in more depth through new exploration and in the end acquire new knowledge and concepts after going through one learning cycle.

Thus it can be concluded that the $5 \mathrm{E}$ learning cycle model is a student-centered learning model and can make students actively involved through various learning experiences that allow students to acquire knowledge. This is in line with the results of research conducted by Superni, et al. (2018) that the 5E learning cycle model has a significant effect on mastery of science concepts. The mastery of science concepts obtained by students with the 5E learning cycle model was significantly better than students who followed the conventional learning model. Other support is shown by the results of research conducted by Hannum, et al. (2019) that the module developed based on the 5E learning cycle is feasible and receives a very good teacher response and can improve analytical thinking skills and completeness of classical learning outcomes can be achieved by $87.5 \%$.

\section{Student Generic Science Skills}

The results of the research on students' generic science skills on electrolyte and non-electrolyte solution materials as a whole are listed in Table 6.

Table 6. Data on Students' Generic Science Skills

\begin{tabular}{llll}
$\begin{array}{l}\text { Pretest } \\
\text { Average }\end{array}$ & $\begin{array}{l}\text { Posttest } \\
\text { Average }\end{array}$ & $\begin{array}{l}\text { N-gain } \\
\text { Average }\end{array}$ & $\begin{array}{l}\text { Classical } \\
\text { Completeness } \\
(\%)\end{array}$ \\
\hline 31 & 88 & 0.8 & 86 \\
\hline
\end{tabular}

Based on Table 6, it is known that the posttest average score is higher than the pretest average score with an average score of 86 . The completeness of students' generic science skills is classically known to be $86 \%$. The increase in students' generic science skills on electrolyte and non-electrolyte solution material was indicated by an average value of 0.8 increase with high criteria. This is in accordance with Lestari and Mujib (2018) that students are said to have generic science skills if there is an increase in the results of the test before being given treatment (pretest) and after being given treatment (postest) and research conducted by Diana and Azizah (2017) that through the application of the learning model Learning cycle by practicing generic science skills, students can build concepts well on the sub-material of the factors that affect the rate of reaction. The indicators of generic science skills trained in this study can be seen in Table 7.

Table 7. Indicators of Generic Science Skills

\begin{tabular}{|c|c|}
\hline No & Generic Science Skills Indicator \\
\hline 1 & $\begin{array}{l}\text { Using the sense of sight in observing experiments } \\
\text { of the electrical conductivity of the solution (lights } \\
\text { and bubbles) }\end{array}$ \\
\hline 2 & $\begin{array}{l}\text { Make the equation for the perfect ionization } \\
\text { reaction and partial ionization of an electrolyte } \\
\text { based on experimental data. }\end{array}$ \\
\hline 3 & $\begin{array}{l}\text { Stating a causal relationship with the ability of a } \\
\text { solution to conduct electricity. }\end{array}$ \\
\hline 4 & $\begin{array}{l}\text { Draw conclusions from a chemical phenomenon } \\
\text { based on previous rules or the results of } \\
\text { experiments to classify solutions based on their } \\
\text { electrical conductivity. }\end{array}$ \\
\hline 5 & $\begin{array}{l}\text { Draw conclusions inductively after experiments or } \\
\text { observations of chemical phenomena by applying } \\
\text { concepts to explain certain events to reach } \\
\text { scientific truth }\end{array}$ \\
\hline
\end{tabular}

Sudarmin (2012)

Students' generic science skills were measured using generic science skills test sheets. The test consists of descriptive questions that contain phenomena regarding the sub-material of electrolyte and non-electrolyte solutions then students are asked 
to determine the appropriate answer which includes generic science skills possessed by students, namely direct and indirect observation, understanding symbolic language, stating causal laws, and logical inference. The skills in observing students get an average score of 96 equivalent to predicate $\mathrm{A}$, the skills to understand symbolic language students get an average score of 85 with the predicate B, the skills to state the law of cause and effect get an average score of 83 with the predicate $\mathrm{B}$, and inference skills logic gets an average value of 87 with the predicate $B$.

The stages of the $5 \mathrm{E}$ learning cycle learning model consist of 5 stages, namely engagement, exploration, explanation, elaboration, and evaluation (Bybee, 2009). At the engagement stage, interesting problems are raised so as to encourage student interest and curiosity to study material related to the phenomena being displayed. Furthermore, at the exploration stage, students carry out a series of investigative activities with the group to find solutions to these problems which require skills in making observations. Next, at the explanation stage, students are expected to be able to explain the concepts related to the results of the investigation inductively.

At this stage students explain the concepts related to the results of the investigation by using generic skills to state the law of cause and effect. At the elaboration stage, students are expected to deepen the concept by applying generic science skills to understand symbolic language and state the causal laws of existing concepts. Then students make conclusions (logical inference) which are expected to lead students to find a solution and new concepts so that it can make it easier for students to understand chemical concepts, especially electrolyte and nonelectrolyte solution material. This is in accordance with research conducted by Diana \& Azizah (2017) that through the application of the 7E learning cycle learning model by practicing generic science skills, students can build concepts well on the sub-material factors that affect reaction rates.

Thus the 5E learning cycle model applied in this study is in accordance with the teaching method according to constructivist theory. Discovery learning where the teacher encourages and guides students to learn and is actively involved with concepts and principles. Through experimental activities students are able to find concepts and principles, especially at the exploration and explanation stages (Slavin, 2011). Students are given the opportunity to first investigate the phenomena contained in the student worksheet before the teacher explains the concepts related to these phenomena. Then when it is related to Vygotsky's theory it is also appropriate where there are four principles of this theory that have appeared in the stages of the 5E learning cycle learning model (Slavin, 2011). Social learning arises when students carry out exploration activities in groups in the exploration phase, the zone of proximal development is applied through giving students assignments in the explanation phase. Personal conversations that may appear during exploration activities and complete assignments in the explanation phase, and scaffolding that appear during the teacher guiding students in the exploration and explanation phases.

Based on this description, it can be concluded that the learning device using the $5 \mathrm{E}$ learning cycle model is effective in improving students' mastery of generic science concepts and skills in electrolyte and non-electrolyte solution material. This is based on the results of research conducted by Zuraida \& Asma (2018) that learning outcomes have increased even beyond a minimum score of 2.67 and achieving completeness individually and classically reaches $100 \%$ after the $5 \mathrm{E}$ learning cycle learning model is applied. Furthermore, Wiyandari, et al (2017) also concluded based on the results of their research that student learning outcomes tended to increase during the learning process using the 5E learning cycle model which was shown by data on increasing learning outcomes of classical absorption in cycle I of $68.26 \%$ and in cycle II it increased to $81.96 \%$.

Saprudin, et al (2010) explained that learning concepts and solving various problems in life, especially those related to science, requires generic science skills. Then Wijaya \& Darmayanti (2019) added that generic science skills are skills that support methodological competencies which are, in fact, one of the individual competencies in facing the era of the industrial revolution 4.0.

This is also supported by the results of research conducted by Yohana, et al (2018) that generic science skills on acid and alkaline materials using inquiry learning can affect students' generic science skills which include indicators of generic science skills in understanding symbolic language, logical consistency and inference. logic is obtained by high criteria. The same thing is also stated in research conducted by Prapti and Eli (2019) that students who use discoverybased learning in the assessment process have improved generic science skills better than those using conventional learning so that the implementation of discovery-based learning has a significant effect on increasing generic science skills.

\section{Conclusion}

Based on the results of this study, it can be concluded that students 'mastery of generic science 
concepts and skills can be improved through learning tools using the $5 \mathrm{E}$ learning cycle model so that the $5 \mathrm{E}$ learning cycle model can be said to be effective in improving students' mastery of concepts and generic science skills.

\section{Acknowledgment}

Thanks are conveyed to Afifuddin Aminin, S.Ag., M.Pd.I as the head of Madrasah Aliyah YKUI Maskumambang Dukun-Gresik who has given the author's permission and opportunity to collect research data

\section{References}

Ariska, H. (2017). Pengaruh Model Pembelajaran Learning Cycle 5E dengan Bagan Dikotomi Konsep terhadap Hasil Belajar Kognitif dan Afektif Siswa Kelas X SMA Negeri 16 Bandar Lampung. Skripsi. UIN Raden Intan Lampung, Bandar Lampung. [Indonesian]

Bybee, R.W. (2009). The BSCS 5E Instructional Model and 21st century skills. Boulevard Colorado Springs:Science Education National Institutes of Health

Diana D.R., \& Azizah U. (2017). Keterampilan Generik Sains Siswa Melalui Penerapan Model Pembelajaran Learning Cycle 7E pada Materi Laju Reaksi di SMA Negeri 1 Taman. Unesa Journal of Chemical Education, 6(2), 162-167 Retrieve from: https://jurnalmahasiswa.unesa.ac.id/index.ph $\mathrm{p} /$ journal-of-chemicaleducation/article/view/20198/18497. [Indonesian]

Hannum F., Sukarmin \& Carl. (2019). Pengembangan Modul Fisika Berbasis Learning Cycle 5E untuk Meningkatkan Kemampuan Berpikir Analitis Siswa. Jurnal Pendidikan IPA, 8(1), 94-109, doi: https://doi.org/10.20961/inkuiri.v8i1.31824

Kusumawati V \& Rivana C.R (2017). Keefektifan Model Learning Cycle 5E terhadap Pemahaman Konsep dan Keterampilan Generik Siswa pada Materi Invertebrata di SMA. Bioma Jurnal Ilmiah Biologi, 5(1), 97-111, doi: https://doi.org/10.26877/bioma.v5i1.1497. [Indonesian]

Lestari Y \& Mujib. (2018). Kemampuan Berpikir Kritis Matematis melalui Model Education Coins of Mathematics Competition (E-COC). Jurnal Matematika, 1(3), 265-274, doi: 10.24042/djm. [Indonesian]

Ministry of Education and Culture. (2016). Permendikbud No 23 Tentang Standar Penilaian
Pendidikan Dasar dan Menengah. Jakarta: Kemendikbud. [Indonesian]

Ministry of Education and Culture. (2016). Permendikbud No 24 Tentang Kompetensi Inti dan Kompetensi Dasar. Jakarta: Kemendikbud. [Indonesian]

Pascalia A., Yuanita L., \& Azizah U. (2019). Validasi Perangkat Pembelajaran Menggunakan Model Advance Organizer. Prosiding Seminar Nasional Kimia dan Pembelajarannya (SNKP). 3 Nopember 2019: 250-259. [Indonesian]

Prapti R.U and Eli R. (2019). Students' Generic Science Skill in Chemistry Learning Using InquiryBased Learning. International Conference on Progressive Civil Society, 317, 234-238, doi: https://doi.org/10.2991/iconprocs-19.2019.49

Purwanto, (2014). Evaluasi Hasil Belajar. Yogyakarta: Pustaka Pelajar. [Indonesian]

Putra F., Nurkholifah I.Y., Subali B., and Rusilowati A. (2018). 5E-Learning Cycle Strategy: Increasing Conceptual Understanding and Learning Motivation. Jurnal Ilmiah Pendidikan Fisika Al-BiRuNi, 7(2), 171-181, doi: 10.24042/jipfalbiruni.v7i2.2898

Ramdoniati N., Muntari, and Saprizal H. (2018). Development of Chemical Learning Materials Based PBI on The Topic of Electrolyte and Nonelectrolyte Solutions. IOSR Journal of Reserach $\mathcal{E}$ Method in Education (IOSR-JRME), 8(3), 35-37, doi: 10.9790/7388-0803043537

Saprudin, Sutarno, \& Liliasari. (2010). Developing Generic Science Skills of Prospective Teacher Through Offline And Online Interactive Multimedia In Physics Learning. Proceeedings of The $4^{\text {th }}$ International Conference on Teacher Education: UPI \& UPSI. 8-10 November 2010: 669-675.

Slavin, R.E. (2011). Psikologi Pendidikan: Teori dan Praktik. Jakarta:PT Indeks. [Indonesian]

Sudarmin. (2012). Keterampilan Generik Sains Dan Penerapannya Dalam Pembelajaran Kimia Organik. Semarang: Unnes Press. [Indonesian]

Sugiyono. (2012). Metode Penelitian Pendekatan Kuantitatif, Kualitatif, dan RED. Bandung: Alfabeta. [Indonesian]

Superni, N.L., Nyoman D., \& Gunamantha, I.M. (2018). Pengaruh Model Siklus Belajar 5E (Engagement, Exploration, Explanation, Elaboration, Evaluation) terhadap Kemampuan Berpikir Kritis dan Penguasaan Konsep IPA. International Journal of Elementary Education. 2(2), 115- 122, doi: http://dx.doi.org/10.23887/ijee.v2i2.14413 [Indonesian] 
Tirmayasari, Wahab, J.A, \& Harjono A. (2019). Validitas Perangkat Pembelajaran IPA Berbasis Masalah Bermuatan Karakter. Jurnal Pendidikan Fisika dan Teknologi, 5(2), 221-227, doi:10.29303/ipft.v5i2.1419. [Indonesian]

Ulia F, Sudarmin, dan Wisnu S. (2017). Pengembangan Petunjuk Praktikum Berbasis Inkuiri Terbimbing Untuk Mengembangkan Keterampilan Generik Sains Siswa. Journal Unnes-Chemistry in Education, 6(2), 15-21, diperoleh dari http://lib.unnes.ac.id/26843/. [Indonesian]

Virtanen, A., \& Päivi, T. (2018). Factors Explaining The Learning of Generic Skills: A Study of University Students' Experience. Journal Teaching in Higher Education:Critical Perspective by Informa UK Limited, trading as Taylor $\mathcal{E}$ Francis Group, 24(7), 880-894, doi: https://doi.org/10.1080/13562517.2018.151519 $\underline{5}$

Wijaya, B.W.K \& Darmayanti, W.S. (2019). Mengembangkan Keterampilan Generik Sains pada Siswa Sekolah Dasar untuk Menyongsong Era Revolusi Industri 4.0. Prosiding Seminar Nasional Dharma Acaraya ke-1. 13 Juli 2019: 8188. . [Indonesian]

Wiyandari N.P., Hatibe A., \& Saehana S. (2017). Implementation of Learning Cycle 5E Model Assisted with Computer Simulation to Increase Physical Learning Outcome. Berkala Ilmiah

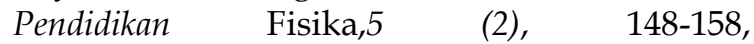
doi:10.20527/bipf.v5i2.3557

Yohana I., Sudarmin S., \& Norasikin S. (2018). The Generic Science Skill Profile of Fourth Grade Students on Acid and Base Topic in Guided Inquiry Learning Model. International Journal of Active Learning, 3(2), 110-116, doi: https://doi.org/10.15294/ijal.v3i2.13485

Zuraida \& Asma C.T. (2018). Penerapan Model Pembelajaran Learning Cycle 5E untuk Meningkatkan Hasil Belajar Siswa Konsep Sistem Pencernaan Makanan pada Manusia di SMP Negeri 2 Bandar Dua. Prosiding Seminar Nasional Biotik: 804-811. . [Indonesian] 